\title{
Nondegradation and Visibility Under the Clean Air Act
}

\author{
David P. Currie†
}

The 1970 amendments to the Clean Air Act ${ }^{1}$ made the federal government for the first time the dominant presence in air pollution control. That statute gave the Environmental Protection Agency (EPA) authority to adopt federal standards of performance for new stationary sources ${ }^{2}$ and emission standards for any source of pollutants found to be especially "hazardous,"3 while strengthening its preexisting authority to regulate emissions from new inotor vehicles. ${ }^{4}$

The central provisions for everyday control of most stationary sources, however, retained a complex systeln administered jointly by the EPA and by the states. Under section 109, the EPA sets standards of ambient air quality designed to make the air harmless to public health and welfare. ${ }^{5}$ Under section 110 , subject to federal supervision, the states subimit plans for the "implementation" or attainment of the ambient standards. ${ }^{6}$ These plans contain enforceable limitations on emissions froin various sources, at levels calculated to assure compliance with air quality standards. ${ }^{7}$

$\dagger$ Harry N. Wyatt Professor of Law, University of Chicago Law School. A.B. 1957, University of Chicago; LL.B. 1960, Harvard University. Chairman, Illinois Pollution Control Board, 1970-1972.

This Article is part of a forthcoming book on the Clean Air Act. The author thanks Mark Reinhardt, J.D. 1978, University of Chicago Law School, for a thoughtful paper that influenced his thinking on the subject.

1. Clean Air Amendments of 1970, Pub. L. No. 91-604, 84 Stat. 1676.

2. Id. § 111(b)(1)(B), codified at 42 U.S.C. § 7411(b)(1)(B) (Supp. I 1979), and as amended by Clean Air Act Amendments of 1977, Pub. L. No. 95-95, 91 Stat. 685.

3. Id. $\S 112(\mathrm{~b})(\mathrm{I})(\mathrm{B})$, codified at 42 U.S.C. $\$ 7412(\mathrm{~b})(\mathrm{1})(\mathrm{B})$ (Supp. I 1979), and as amended by Clean Air Act Amendments of 1977, Pub. L. No. 95-95, 91 Stat. 685.

4. Air Quality Act of 1967, Pub. L. No. 90-148, \& 202, 81 Stat. 485, codified at 42 U.S.C. $\S 7521$ (Supp. I 1979), and as amended by Clean Air Amendments of 1970, Pub. L. No. 91-604, 84 Stat. 1676, and Clean Air Act Amendments of 1977, Pub. L. No. 95-95, 91 Stat. 685.

5. Clean Air Amendments of 1970, Pub. L. No. 91-604, § 109, 84 Stat. 1676, codificd at 42 U.S.C. $\$ 7409$ (Supp. I 1979). Primary standards must be "requisite to protect the public health" and allow "an adequate margin of safety." Secondary standards must be "requisite to protect the public welfare from any known or anticipated adverse effects associated with the presence of such air pollutant in the ambient air."

6. Id. $\S 110$, codified at 42 U.S.C. $\$ 7410$ (Supp. I 1979).

7. I have discussed these provisions at length in Currie, Federal Air-Quality Standards and Their Implementation, 1976 AM. B. Found. RES. J. 365. 
In Sierra Club v. Ruckelshaus, ${ }^{8}$ the District Court for the District of Coluinbia in 1972 enjoined the EPA Administrator froin approving impleinentation plans that did not contain provisions forbidding "significant deterioration" of air quahty in areas presently cleaner than required by the air quality standards.

The doctrine of prevention of "significant deterioration," or "nondegradation," of clean areas was not original to the Sierra Club decision.? The basic policy reflected by the doctrine is attractive enough: while we inay be stuck with sone existing pollution probleins, we ought to avoid letting the air get any worse than it already is. The statute as it stood when Sierra Club was decided, however, afforded precious little basis for the decision. ${ }^{10}$

In response to the decision, the EPA adopted new regulations aunending existing impleinentation plans in order to prevent significant deterioration of areas then ineeting ambient standards. ${ }^{11}$ In accord with the preventive purpose of the nondegradation requirement, the regulations required permits for construction or modification of specified types of major emission sources. ${ }^{12}$ A permit could be issued only upon a showing that the source would employ the "best available control technology" for particulate matter and sulfur dioxide ${ }^{13}$ and that its emissions, "in conjunction with" those of other new sources, "will not violate the air quality increments applicable" in any area. ${ }^{14}$

The "increments" were central to the purpose of the regulations. Annual annbient concentrations of particulates and sulfur dioxide were not to be increased beyond 1975 levels by more than ten and fifteen

8. 344 F. Supp. 253 (D.D.C. 1972), aff d mem, 4 E.R.C. 1815 (D.C. Cir.), aff d by an equally divided Court, 412 U.S. 541 (1973).

9. For a thorough exposition and analysis of the doctrine in general, see Hines, $A$ Decade of Nondegradation Policy in Congress and the Courts: The Erratic Pursuit of Clean Air and Clean Water, 62 IowA L. REv. 643 (1977). "Since 1966, except for brief periods of backsliding, federal pollution control programs have been committed publicly to a policy of nondegradation." Id. at 645.

10. See Currie, supra note 7, at 373-75; Hines, supra note 9, at 964-67. The Court in Sierra $C l u b$ had relied on legislative history endorsing nondegradation and on the statement in $\$ 101$ (b) of the Act (codified at 42 U.S.C. $\$ 7401(b)(1)$ ) that one of the purposes of the statute was "to protect and enhance the quality of the Nation's air resources ...." The language of the Supreme Court's later opinion in Union Elec. Co. v. EPA, rejecting claims that an implementation plan should be disapproved if stricter than necessary or practicable, unmistakably refuted this reasoning:

$\$ 110(a)(2) \ldots$ sets out eight criteria that an implenentation plan must satisfy, and provides that if these criteria are inet ... the Administrator "slall approve" the proposed state plan. The mandatory "slall" makes it quite clear that the Administrator is not to be concerned with factors other than those specified.

427 U.S. 246, 257 (1976).

11. 39 Fed. Reg. 42,510 (1974), as amended in 40 C.F.R. $\$ 52.21$ (1975).

12. 40 C.F.R. $\S 52.21$ (d) (1975).

13. Id. $\$ 52.21$ (d)(2)(ii).

14. $I d . \S 52.21(\mathrm{~d})(2)(\mathrm{i})$. 
micrograms per cubic meter, respectively. ${ }^{15}$ The states were generally authorized, however, subject to federal review, to assure consistency with a variety of specified factors, to reclassify individual areas to give either nearly absolute protection against deterioration or none at all. ${ }^{16}$ Attacked froin both sides, these regulations were upheld in all respects by the Court of Appeals for the District of Columbia Circuit in Sierra Club v. EPA. ${ }^{17}$

In 1977, Congress enacted complex provisions of its own for the "prevention of significant deterioration" (PSD). ${ }^{18}$ Under section 110 (a)(2)(J), no implementation plan may be approved unless it meets the requireinents of the new part $C$ of the statute. The central provision of part $C$ is section 161, which requires that each plan "shall contam emission limitations and such other measures as may be necessary . . . to prevent significant deterioration of air quality" in regions not violatimg ambient standards. ${ }^{19}$

The basic structure of the earher regulations is preserved in section 165 of the new statute. Under this section a permit is required for major new stationary sources. ${ }^{20}$ The permittee inust show that his proposed facility will employ "the best available control technology"21 and will not cause violations of prescribed imcrements above existing ambient concentrations. ${ }^{22}$

In Alabama Power Co. v. Costle, the District of Columbia Circuit in a per curiam opmion construed a number of the new provisions, taking the unusual step of writing fuller opimions in support of its con-

15. Id. $\$ 52.21(\mathrm{c})(2)$, (3). Shorter term limits were also prescribed.

16. $I d . \$ 52.21(\mathrm{c})(3)$. The federal government, subject to the same review, could redesignate any of its own lands to require greater protection notwithstanding a state's classification. Indian tribes were substituted for states with respect to reclassification of Indian lands over which the state had no jurisdiction. The zone systein was adopted only after the EPA had solicited comments on four alternate strategies. 38 Fed. Reg. 18,986 (1973).

17. 540 F.2d 1114 (D.C. Cir. 1976). The court reaffirmed the earher Sierra Club decision, unconvimcingly distinguishing the Union Electric opinion quoted im note 10 supra.

Although the Court stressed the "shall approve" language of Section 110(a)(2), its construction was founded on a concern that the congressional mandate of prompt implementation of pollution plans not be disserved. The Court was not presented with the distinct question whether the "shall approve" Ianguage of Section 110(a)(2) must be read to subvert the concomitant congressional directive that significant deterioration of air cleaner than the national standards be prevented.

540 F.2d at 1129. For extensive criticisin of the decision, see Himes, supra note 9, at 681-87.

18. 42 U.S.C. $\$ \$ 7470-7479$ (Supp. I 1979). The preexisting regulations remain effective until approval of revised plans, subject to certain overriding provisions of the new statute. $I d$. $\S 7478$.

19. Id. \& 7471 .

20. Id. $\$ 7475(\mathrm{a})(1)$.

21. Id. $\$ 7475(\mathrm{a})(4)$.

22. Id. $\$ 7475(\mathrm{a})(3)$. For a detailed explication of the current requirements, see Raffe, Prevention of Significant Deterioration and Nonattainment Under the Clean Air Act-A Comprehensive Review, Env. Rep. Monograph No. 27 (1979). 
clusions several months later. ${ }^{23}$ The EPA responded to the initial decision by proposing revised regulations. ${ }^{24}$ Part I of this Article will examine the new PSD provisions and their underlying policies witl particular einphasis on the permit rcquirenent, the "best available control technology" requireınent, and the allowable ambient incrennents. Part II evaluates the provisions for protection of visibility in scenic areas, which Congress also adopted in part $\mathrm{C}$ in 1977.25

\section{I}

\section{SigNIFICANT DETERIORATION}

\section{A. The Permit Requirement}

\section{Geographic Scope}

"No major emitting facility," according to section 165(a), "may be constructed in any area to which this part applies unless - (1) a permit has been issued ... in accordance with this part . . .."26

The "area[s] to which this part applies" seem to be indicated by section $161,{ }^{27}$ which requires each impleinentation plan to contain ineasures "to prevent significant deterioration of air quality in each region (or portion thereof) identified pursuant to" section 107(d)(1)(D) or (E). Section 107 provides for dividing the country into "air quality control region[s]," and section 107(d) requires the states, subject to EPA inodification, ${ }^{28}$ to classify those regions "or portions thereof" according to whether or not they satisfy ambient standards. ${ }^{29}$ The areas to be listed under paragraphs (D) and (E) are those not violating, or not shown to be violating, eitler primary or secondary standards. ${ }^{30}$ It follows that the nondegradation provisions "apply," within the meaning of section 165 (a), to the relatively clean air quality areas whicli the regulations call "attainment" areas. ${ }^{31}$

The language of section 107(d) makes clear that an area is to be classified as an "attainment" area if it complies with standards applicable to any one pollutant. ${ }^{32}$ The reference to "portions" of a region means that the requireinents apply although ambient standards are not

23. 606 F.2d 1068 (D.C. Cir. 1979); 13 E.R.C. 1993 (D.C. Cir. 1979).

24. 44 Fed. Reg. 51,924 (1979).

25. 42 U.S.C. $\$ 7491$ (Supp. I 1979).

26. Id. $\$ 7475(\mathrm{a})$.

27. Id. $\$ 7471$.

28. Id. $\S 7407$ (d)(2).

29. Id. $\S 7407(d)(1),(4)$.

30. Id. \& 7407(d)(1), (2), (4).

31. Cf. id. $\S 7501$.

32. Id. $\S 7407(\mathrm{~d})(1)(\mathrm{D})$, (E). 
met elsewhere in the same air quahity control region. ${ }^{33}$ Both these conclusions make sense in terms of the purpose of the nondegradation requirements. Neither a particulate violation in Detroit nor an oxidant violation in Hamtramck justifies allowing particulate levels to deteriorate in the latter.

Recognizing that winds may carry pollutants a considerable distance from where they are emitted, ${ }^{34}$ Congress sensibly required in section 165 that a permit applicant show there will be no prohibited deterioration not only in its immediate area but also im "any area to which this part apphes."35 For the sanie reason, in adopting regulations implementimg the 1977 statute, the EPA reaffirmed its "policy" of requiring preconstruction review of sources in areas wliere ambient standards are not inet to assure against forbidden degradation "in an affected clean area."36 While this decision reflects sound policy, it does not appear to be sustamable as an imterpretation of section 165(a). That section carelessly requires permits only for those sources which are "constructed in any area to which this part applies," not to all those affecting sucli an area. ${ }^{37}$

Accordingly, the District of Columbia Circuit, in Alabama Power, ${ }^{38}$ struck down the EPA's permit requirement as too broad, lolding that a source located in a nonattainment area and causing deterioration of a clean portion of the same state is not "constructed im any area to whicls this part applies" within section $165(\mathrm{a})$. On the other hand, relying chiefly on section 160(4)'s declaration tliat one purpose of the PSD provisions was to prevent sources im one state from causing deterioration in another, ${ }^{39}$ the court upheld the requirement of a permit for sources in polluted areas affecting clean portions of other states: "[A]n area within a 'nonattainment area' is subject to the PSD part if that area is put to use as a location for a stationary source tliat has or will liave a substantial adverse impact on air quality in a clean air area of another state."40

33. Id. $\$ 7407(\mathrm{~d})(1)$.

34. H.R. REP. No. 294, 95th Cong., 1st Sess. 135, reprinted in [1977] U.S. CODE CONO. \& AD. News 1077, 1214.

35. 42 U.S.C. $\$ 7475(a)(3)$ (A) (Supp. I 1979).

36. 43 Fed. Reg. 26,388, 26,397-98 (1978). See id. at 26,406 (adding 40 C.F.R. $\$ 52.21(1)(5)$ ), exeinpting froin PSD review sources subject to nonattainment requirements under $42^{\circ}$ U.S.C. $\$ 7503$ if they "would impact no area attaining the national ambient air quality standards."

37. 42 U.S.C. $\$ 7475$ (a) (Supp. I 1979).

38. 606 F.2d 1068, 1082-83.

39. 42 U.S.C. \& 7470(4) (Supp. I 1979). The court also invoked \& 110(a)(2)(E)(i), codified at 42 U.S.C. $\$ 7410(a)(2)(E)(i)$, which requires that implementation plans protect against significant deterioration in other states, and $\$ 126$, codified at 42 U.S.C. $\$ 7426$, which provides a mechanism for abating interstate violations of ambient standards.

40. 606 F.2d at 1084 . 
The court's interpretation seeined to strain severely the statutory language. The statutory reference to the "area to which this part apphes" hardly suggests that each individual source is to be considered a separate "area," as the court implied. Moreover, out-of-state deterioration is not the sole concern expressed by section 160; the same section clearly expresses the desire to prevent harm "notwithstanding attainment" of ambient standards, to protect scenic areas, to preserve "existing clean air resources," and to assure "careful evaluation of all the consequences" before permitting "increased air pollution in any area to which this section applies," 41 all without regard to whether the new source is in the same state as the risk of deterioration. Thus, if every source that comes within the purposes expressed in section 160 is located in an "area to which this part applies," as the court's invocation of that section suggested, it should be immaterial where a source is to be constructed so long as it threatens deterioration of an area ineeting ambient standards.

The EPA's broad requirement of a permit for any source threatening deterioration of a clean area, while not supported by section 165 , should have been sustained under section 161, which requires every implementation plan to contain "such measures as may be necessary . . . to prevent significant deterioration . . . in each region . . . identified pursuant to [section 107]."42 Because of the risk of harm froin outside sources of deterioration, this provision cannot be achieved without a permit requirentent in the implementation plan broader than that of section 165. The court of appeals, noting that "government counsel disclaimed reliance on section 161," rejected its application without further explanation.

In its second Alabama Power opimion, the court backed away from its intial conclusion. Although the prevention of interstate deterioration was indeed a congressional concern, the statute provided alternative ineans for avoiding it. Section $110(a)(2)(E)(i)^{43}$ required every implementation plan to contain measures preventing PSD violations in other states, and section 126 furnished a remedy. ${ }^{44}$ Moreover, "in view of the legislative desire to prevent interstate impacts," section 161, dismissed summarily before, "grants to the Administrator the power to promulgate rules requiring that SIPs adequately address the problem." Thus, the court was "no longer confident" that section 165 itself required permits for sources in dirty areas causing interstate deteriora-
41. 42 U.S.C. § 7470(1), (2), (3), (5) (Supp. I 1979).
42. Id. $\S 7471$.
43. Id. $\$ 7410(\mathrm{a})(2)(\mathrm{E})(\mathrm{i})$.
44. Id. $\$ 7426$. 
tion. ${ }^{45}$ The court did not suggest that its new reading of section 161 would also apply, as it should, to all intrastate situations.

Nevertheless, this aspect of the Alabama Power decision may inake little practical difference. Although the EPA has identified nuinerous regions in which one or nore of the ambient standards are violated, it has also emphasized that "virtually every area in the country shows attainment for at least one pollutant." 46 Thus, regardless of the validity of extending the permit requirement to sources constructed in areas meeting none of the ambient standards, the EPA seems correct in its conclusion that "PSD review will be a requisite virtually everywhere." ${ }^{\prime 47}$ Moreover, once the permit requirement is applicable, the applicant under section 165(a)(3) will have to demonstrate that the proposed construction or inodification will not cause violations of the statutory imcrements "in any area to which this part apples," which for the above reason means "virtually everywhere."

\section{The Size Limitation}

Section 165 requires only a "inajor emitting facility" to obtain a permit. "Major emitting facility," under section 169(1), "Ineans any of the following stationary sources of air pollutants which emit, or have the potential to emit, one hundred tons per year or more of any air pollutant from the following types of stationary sources." There follows a long hist of stationary sources ranging from pulp mills to mitric acid plants and large municipal incinerators. A catchall clause adds that the term "also includes any other source with the potential to emit two hundred and fifty tons or more per year of any air pollutant"48 but "shall not imclude new or inodified facilities which are nonprofit healtlı or education institutions which have been exempted by the State."49

The exemption of smaller sources from the permit requirement is a reflection of administrative costs; as the District of Coluunbia Circuit said im upholding a similar provision in the earlier regulations,

45. 13 E.R.C. 1993, 2012-16 (D.C. Cir. 1979). The court did say that outside sources affecting federal lands and Indian reservations "raise similar problems of interjurisdictional pollution" and thus could be dealt with under § 161. Id. at 2016.

46. See 43 Fed. Reg. 8962, 8963 (1978).

47. Id.

48. 42 U.S.C. $\$ 7479$ (1) (Supp. I 1979). Contrast the definition of "major stationary source" for other purposes (including $\S 111$ ) in $\S 302(j)$, codifed at 42 U.S.C. $\S 7602(j)$, which includes any stationary source with the potential to emit 100 tons of any pollutant.

49. The authorization for states to exeinpt from the permit requirement "nonprofit health or education facilities" seems to be without justification. Schools and hospitals may be socially useful, but so are inany factories, and their utility is no reason to refrain from making sure they do not violate pollution laws. Indeed, these institutions are not exempted from the substantive nondegradation requirement of $\S 161$, and they should be required to get permits like everyone else in a similar position. 
"[r]eview of every new source of pollution clearly would be impossible since every gas- or oil-heated house is a source of some pollution." 50 Moreover, the permit provision is only one means, while clearly a crucial one, of enforcing the general command of section 161 that the plan be sufficient "to prevent significant deterioration of air quality . . . ."s1 The House Report left no doubt that sources exempt from the permit requirement must be controlled to satisfy the provisions that becaine section 161: "States would not be required to apply the permit process to sinaller new sources, although the State plan would still be required to contain such measures as are necessary to prevent significant deterioration." 52 The importance of such alternative measures is illustrated by the problem of mobile sources, for the cumulative effect of a large number of new vehicles may render the most stringent limitations on stationary sources wholly inadequate to achieve the statutory purpose. ${ }^{53}$

The operative criterion for determining whether section 165 requires a permit is "the potential to emit" the prescribed number of tons per year ${ }^{54}$ of "any air pollutant." On its face the word "potential" suggests a possibility or a risk; not surprisingly, the EPA interpreted it to mean what would be emitted during operation at capacity without pollution controls. ${ }^{55}$ The District of Columbia Circuit in Alabama Power

50. Sierra Club v. EPA, 540 F.2d 1114, 1134 (D.C. Cir. 1976). The Illinois Pollution Control Board similarly exempted small sources from permit requiremeuts, though not from emission limitations, for similar reasons. See In re Emission Standards, 4 Ill. P.C.B. 298, 304 (1972).

51. 42 U.S.C. \& 7471 (Supp. I 1979).

52. H.R. ReP. No. 294, 95th Cong., 1st Sess. 171, reprinted in [1977] U.S. CoDE CoNG. \& AD. News 1077, 1250. See also Alabama Power Co. v. Costle, 13 E.R.C. 1993, $2010-12$ (D.C. Cir. 1979).

53. While the introductory clause of the definition of "major emitting facility" twice refers to "stationary sources" and the accompanying examples are still stationary, the catchall clause is not specifically so limited; it includes "any other source" of the prescribed capacity. The minimum capacity of 250 tons is probably large euough, however, to exclude all known mobile sources. Uncontrolled autoinobiles were estimated to emit on the average 87 grams of carbon monoxide per inile. See D. Currie, Cases \& Materials on Pollution 344 (1975). At 10,000 miles per year, such a car would emit 870,000 grams of carbon monoxide; there are 908,000 grams in a single ton.

54. As the EPA has ruled, the "per year" provision seems to indicate the emissions that would occur if the facility operated at peak load throughout an eutire year, not to contemplate exemption of large sources that will be operated only part of the time. 43 Fed. Reg. 26,383, 26,383, 26,404 (1978). See also 44 Fed. Reg. 51,924, 51,952 (1979) (proposing revised 40 C.F.R. $\S \S 51.24(\mathrm{~b})(3), 52.21(\mathrm{~b})(3)$ : "Annual potential shall be based on the maximum annual rated capacity of the stationary source assuming continuous year round operation.").

55. See 43 Fed. Reg. 26,383, 26,404 (1978) (adding 40 C.F.R. $\$ \S 51.24(b)(3), 52.21(b)(3)) ; 43$ Fed. Reg. at 26,391-92, contrasting the term "allowable emissions" in § 165(b), codified at 42 U.S.C. \$ 7475(b) (Supp. I 1979). Cornputing "potential" emissions on the EPA's basis, however, could present ambiguities in soine cases. In the case of sulfur oxides, for example, emissions depend in part upou the composition of the fuel consumed; the purpose of the requirement suggests, though it is not clear, that "poteutial" emissions be calculated on the basis of the highest sulfur fuel that the facility can burn and that is reasonably available. The EPA regulation pro- 
disagreed: “The 'potential to emit' . . . must be calculated on the assumption that air pollution control equipment incorporated into the design of the facility will function to control emissions in the manner reasonably anticipated when the calculation is made."56 But a principal reason for requiring permits is to provide assurance through prior government scrutiny that control equipinent will "function . . . in the manner reasonably anticipated" by its owner. Similarly, while the court argued that " $[t]$ he purpose of Congress was to require a permit before major amounts of emissions were released,"57 that purpose cannot be accoinplished with assurance if the owner is allowed to predict the effectiveness of his own controls. In straining the statute's language of possibility into a prediction of actual emissions, the court has both impaired the statutory purpose and made the polluter the judge in his own cause. ${ }^{58}$

\section{The Relevant Pollutants}

As related in the preceeding discussion, the permit requirement applies to major sources of "any air pollutant." The uncompromising generality apparent in this term is confirmed by the definition im section 302(g), which embraces "any physical, chemical, biological, radioactive . . . substance or matter which . . . enters the ambient air." ${ }^{\prime} 9$ Yet the implementing provisions of part $\mathrm{C}$ appear basically to tie deterioration rcquirements to those pollutants for which ambient standards have been adopted. Section 161 makes provisions against deterioration necessary parts of plans for implementing ambient standards, and it requires protection of "air quality" only im areas in which ambient standards are not violated. Section 163 provides numerical increment limits for sulfur oxides and particulates; ${ }^{60}$ section 166(a) requires the EPA to adopt "regulations to prevent . . . significant deterioration of air quality" from "hydrocarbons, carbon nnonoxide, photo-chemical

vided that "enforceable permit conditions on the type or amount of materials combusted or processed may be used in determining the potential emission rate of a source." 43 Fed. Reg. at $26,404$.

The EPA's interpretation of "potential" emissions, moreover, has implications for the "bubble" issue. See text accompanying notes 77-78 infra.

56. Alabama Power Co. v. Costle, 606 F.2d at 1076; 13 E.R.C. at 2003. The EPA's proposed new regulations conform to this interpretation: "Potential to emit' means the capability at maximum design capacity to emit a pollutant after the application of air pollution control equipment." 44 Fed. Reg. 51,924, 51,952 (1979) (proposing new 40 C.F.R. $\$ \$ 51.24(b)(3), 52.21(\mathrm{~b})(3)$ ).

57. 606 F.2d at 1076; 13 E.R.C. at 2003.

58. The committee reports are of no assistance. The Conference Committee merely followed the word "potential" with the uninformative parenthetical "design capacity," H.R. REP. No. 564, 95th Cong., lst Sess. 152, reprinted in [1977] U.S. Code CoNG. \& AD. News 1077, 1533, and the other reports said nothing about it.

59. 42 U.S.C. $\$ 7602$ (g) (Supp. I 1979).

60. Id. $\$ 7473$. 
oxidants, and nitrogen oxides" by August 7, 1979, and from other pollutants "not more than 2 years after . . . promulgation" of applicable anıbient standards. ${ }^{61}$ Section 165(a)(3) makes it a condition of permit issuance that the new facility will not cause violations of ambient standards, increments, or applicable emission and performance standards; ${ }^{62}$ section 165(a)(4) makes another condition the use of best available controls "for each pollutant subject to regulation under this chapter," ${ }^{63}$ which must nean those actually regulated since it otherwise would be as comprehensive as if there were no qualifying clause.

In short, while an argument could have been made that the underlying policy required prevention of degradation by discharges of otherwise unregulated pollutants, ${ }^{64}$ the statutory deterioration provisions primarily address the pollutants subject to the implementation plans of which they are to form a part. Evidently the broader language of section 165 is an oversight; requiring a permit to construct a facility emittimg only contaminants not subject to substantive limitations would be a waste of effort. Accordingly, it is not surprising, though it appears inconsistent with the statute, that the EPA has narrowed the definition of a major facility to one with the potential to emit the prescribed amount of "any air pollutant regulated under the Clean Air Act."65

\section{New and Modified Sources}

The permit requirement of section 165 (like the new-source performance standards of section 111$)^{66}$ applies only to facilities "on which construction is commenced" after the date of enactment. ${ }^{67}$ " "Construction" " is defined to include "modification (as defined im sec-

61. Id. $\$ 7476(\mathrm{a})$.

62. Id. \& 7475(a)(3).

63. Id. \& 7475(a)(4).

64. See Hines, supra note 9, at 701.

65. 40 C.F.R. $\S \S 51.24(\mathrm{~b})(1), 52.21(\mathrm{~b})(\mathrm{l})$ added by 43 Fed. Reg. 26,403 (1978). For what the EPA means by this phrase, see text accompanying notes 120-30 infra. Note that it includes pollutants for which there are no ambient standards, in accord with the evident requirement of best technology for pollutants regulated anywhere in the Act. Alabama Power, 606 F.2d at 1085, rejected an industry argument that permits were required only for sources of particnlates and of sulfur oxides; it did not pass on the validity of the EPA's limitation to regulated pollutants.

66. 42 U.S.C. \& 7411(a) (Supp. I 1979).

67. Id. $\$ 7475$ (a). Despite the plain statutory cutoff date of August 7, 1977, the EPA Administrator determined not to apply the permit requirement of $\S 165$ to sources that obtained permits under the existing regulations before March 1978. Rejecting a challenge to this postponement, the Court of Appeals for the District of Columbia Circuit pointed out that the $\$ 165$ date was inconsistent with § 168, which provided that existing regulations would reinain in effect until state plans were revised to incorporate the new statutory requirements, with exceptions that did not include § 165. The EPA, the court held, had the power under $\$ 301$ to adopt regulations to implement the transition between old and new rules in the face of imconsistent statutory commands. Citizens to Save Spencer County v. EPA, 600 F.2d 844 (D.C. Cir. 1979). The problem has been cured by time, but Congress imight have been inore careful. 
tion 7411(a) . . .),"68 and a complex formula is provided for determining when construction has "commenced."69 Two aspects of this definition require particular attention: whether only "major" modifications are included, and the applicability of the so-called "bubble" concept.

\section{a. Minor Modifications of Major Sources}

In order to avoid unnecessary administrative costs, Congress required permits only for the construction of "major" sources posing significant environmental risks. It would seem to follow, as the EPA ruled, ${ }^{70}$ that only "major" nıodifications were subject to the permit requirenient - those that mcreased potential emissions by the prescribed 100 or 250 tons per year. Once again the court in Alabama Power disagreed, spelling out the plain provisions of the statute: "No major emitting facility" may be "constructed" without a permit;" "construction" includes "n1odification"; 72 and "modification" ineans any change "which increases the amount of any air pollutant emitted . . . or which results in the emission of any air pollutant not previously emitted"73 without regard to the amount of the increase. ${ }^{74}$ Thus, a trivial modification of a large plant requires a permit, contrary to the apparent policy of the nuajor-source limitation. ${ }^{75}$ The court questionably suggested that "administrative necessity" would nonetheless empower the EPA to exenupt "de minimis" nrodifications, as the EPA has simce proposed. ${ }^{76}$

68. 42 U.S.C. $\$ 7479(2)$ (e) (Supp. 1 1979).

69. Id. $\S 7479(2)(\mathrm{A})$. For interpretation of this complicated but temporary provision, see Montana Power Co. v. EPA, 608 F.2d 334 (9th Cir. 1979).

70. 40 C.F.R. $\$ \$ 51.24(\mathrm{~b})(2), 52.21(\mathrm{~b})(2)(1978)$.

71. 42 U.S.C. $\$ 7475$ (a) (Supp. 1 1979).

72. Id. $\$ 7479(2)(\mathrm{C})$.

73. Id. $\$ 7411(\mathrm{a})(4)$.

74. Alabama Power Co. v. Costle, 606 F.2d at 1081; 13 E.R.C. at 2042-43.

75. The following argunent might be advanced in support of the requirement of a permit for a minor inodification of a major source. "Modification" of a "major emitting facility" not only assures preconstruction clearance of significant new emissions; it also triggers the applicability of the requirenent, 42 U.S.C. $\$ 7475$ (a)(4), of best available control technology. Even a modification that results only in insignificant new emissions may facilitate retrofitting of controls on the modified facility, so that it may furnislı an appropriate occasion for actually improving air quality. A permit might therefore be worth its cost to ensure sucl improvement. Not only does this argument depend upon the debatable premise that a ban on "deterioration" was meant to improve air quality, see text accompanying notes 87-91 infra, it is also difficult to reconcile with the clear statutory limitation to those inodifications that increase potential emissions.

76. See 44 Fed. Reg. 51,924, 51,952 (1979) (proposing revised 40 C.F.R. $\$ \$ 51.24(\mathrm{~b})(2)(\mathrm{i})$, 52.21 (b)(2)(i), which would define "modification" as a "major modification," resulting in a "significant" increase in potential emissions), and 44 Fed. Reg. at 51,937, where a table defines "significant" increases as, e.g., 10 tons per year of particulates, sulfur dioxide, or nitrogen dioxide, and a whopping 100 tons per year of carbon monoxide. Whether the court would agree that emissions of this magnitude are "de minimis" reinains to be seen. 
It would be preferable for Congress to rectify the apparent inconsistency by applying the permit requirement only to major inodifications.

\section{b. The "Bubble" Concept}

Section 111(a), made applicable to the PSD provisions by section $169(2)(C)$, defines a "modification" to include any change "which increases the amount of any air pollutant emitted by such source."77 Industry predictably argued that an entire plant should be viewed as a single "source" (thus the term "bubble") in determining whether modification or construction of a single machine "increases" emissions within the meaning of the statute. If reductions of emissions from other equipment within the same plant may be offset agamst emissions from the new or modified machine, the occasions requiring permits will be sharply reduced. The EPA gave industry half a loaf, allowing offset when an existimg machine was altered but not when a new one was built. $^{78}$

The District of Columbia Circuit in Asarco, Inc. v. EPA struck down the regulation allowing this limited offset in the context of newsource performance standards (NSPS) under section 111 itself. $^{79}$ The EPA, observing that the purpose of the nondegradation requirements was to protect the ainbient air froin further deterioration, declined to follow the apparent implication of this decision in its application of section 165. Yet it refused to accept the full consequences of its argument, adhering in the PSD context to its origmal position of allowing offset when a single machine was modified but not when a new one was erected. ${ }^{80}$ The statute, however, expressly equates the definitions of "inodification" under sections 165 and 111 (under NSPS and PSD); the EPA's distinction appeared to be on very shaky legal ground.

In the Alabama Power case the saine court that had decided Asarco held that under the PSD provisions the EPA was wrong to restrict offset. The court reasoned that, absent a "net increase" in emission potential, there is no modification. ${ }^{81}$ At first glance this decision seems squarely contradictory to $A$ sarco - offset is never allowed under section 111, always under section 165 . In fact, botl decisions focused upon the unfortunate terminology employed by the regulations, purporting to leave the basic question whether offset should be allowed largely to EPA discretion.

The vice of the section 111 regulation in Asarco was that, contrary

77. 42 U.S.C. $\$ 7411$ (a)(4) (Supp. I 1979).

78. 40 C.F.R. $\$ \S 60.2(d)(1), 60.14$ (d) (1977).

79. Asarco, Inc. v. EPA, 578 F.2d 319 (D.C. Cir. 1978).

80. See 43 Fed. Reg. at 26,394, 26,406-07 (adding 40 C.F.R. $\$ 52.21$ (j)(2)(ii), (4)).

81. Alabama Power Co. v. Costle, 606 F.2d at 1081. 
to the statutory definition of a "source" as a "facility," it defined "source" to mclude a "combmation of . . . facilities." While the PSD regulation contained the same language and thus was remanded for offending Asarco, the court in Alabama Power also struck down a provision that "there shall be taken into account no emission reduction achieved elsewhere in the source" 82 - a provision that contradicted the statutory requirement of an increase in emissions from the "source" as a whole. Both parts of the Alabama Power opinion stressed that it was up to the EPA to determine whether to include an entire plant within the definition of a "facility." 83

The EPA responded to Alabama Power by proposing to adopt the industry position that a "source" embraces an entire plant, and to authorize offset when a single machine is either constructed or modified. ${ }^{84}$ Its reasoning was straightforward in that, as it had said before, only net increases in einissions were relevant; "emission reductions beyond existimg levels . . . are ordinarily unnecessary to meet the purpose of the PSD program." 85

It can be argued that the EPA has too narrowly interpreted those purposes. Some of the policy reasons given by the House Report for establishing PSD-such as the inadequacy of existing ambient standards to protect liealth and welfare, and the desire to encourage the development of technology ${ }^{86}$ - suggest it may be desirable to reduce existing pollution levels $\mathrm{m}$ areas complying with ambient standards. Moreover, the section 101 statement relied on by the court in the first Sierra Club case in support of the origmal PSD requirement made it federal policy not only to "protect" but also to "enhance" existimg air

82. Id. at 1077, 1081. See 40 C.F.R. $\$ \S 52.21($ b)(4), (5), (j)(2)(ii) (1978).

83. In its second Alabama Power opinion, the court altered somewhat its focus. The invalidated restriction on offset was not mentioned. The regulation no longer, "in light of our dccision in this case, allow[ed] offsets within any 'combination of facilities.' " And the court came close to saying that the bubble concept was not merely permitted but required by the statute in the case of PSD, sharply distimguishing $\S 111$ : "Congress wished to apply the pernit process . . . only where industrial changes might increase pollution in an area, not where an existing plant changed its operation in ways that produced no pollution increase." Yet the court reaffirmed that "the offsetting changes must be within the same source, as defined by the EPA," in a paragraph beginning, " $t \mathrm{t}$ ]he Agency retains substantial discretion in applying the bubble concept." 13 E.R.C. at 204345.

84. A "source" is to be a "structure, building, facility or installation," which is to be "any grouping of pollutant-emitting activities which are located on one or inore contiguous or adjacent properties and which are owned or operated by the same person (or by persons under cominon control)"; a "inodification" is to be any "change ... or series of contemporaneous physical changes . . that would result in a significant net increase in that source's potential to enit the pollutant . . ." See 44 Fed. Reg. 51,924, 51,948, 51,952 (1979) (proposing revised 40 C.F.R. $\S 51.24(\mathrm{~b})(2)(\mathrm{i}),(4),(5)$, and $52.21(\mathrm{~b})(2)(\mathrm{i})(4),(5))$.

85. 44 Fed. Reg. at 51,932 .

86. H.R. REP. No. 294, 95th Cong., 1st Sess. 106-10, 133-36, reprinted in [1977] U.S. CoDE CONG. \& AD. News 1077, 1184-88, 1211-15. 
quality; and this language is repeated in section 160's declaration of the policies of the statutory PSD provisions theinselves. ${ }^{87}$ Thus it is possible that subjecting new or modified machines to PSD requirementswhich include best control technology as well as permits-even if they do not cause a net increase im potential emissions would serve the statutory purposes.

A close examination of the statute and its history, however, suggests that Congress had no such intention. The central statutory requirement is that clean areas be protected from "significant deterioration." Indeed, "Prevention of Significant Deterióration" is the title of the entire part $\mathrm{C}$ of the statute. The term "deterioration" indicates a desire to mamtain existing quality, not to improve it. The House Report is replete with references to minimizing "increases" in emissions and "decline" or "degrad[ation]" of air quality, and to "retain[ing]" clean air. ${ }^{88}$ Section 160(5) declares that one purpose of PSD is to assure careful consideration before "any decision to permit imcreased air pollution;" quirements apply only to those modifications which "[increase] the amount of any air pollutant emitted." $"$ In this context, the statutory reference to "enhanc[ing]" air quality seeins an unconsidered exercise in boilerplate; if Congress had intended to seize upon modifications as the occasion for requiring the maximum practicable reduction of existing emissions, it does not seem likely that it would have included only those modifications that increased emissions.

Moreover, the EPA identified another critical consideration. If each inachine were designated a separate "source," "[l]arge new plants could be constructed at one site as a collection of individual process units, each below the potential-to-emit threshold, and thereby escape review altogetlier." ${ }^{.91}$

On the other hand, if, as the EPA proposes, an entire plant is declared a single "source" or "facility," the entire plant will become subject to section 165 's best-technology requirement whenever net emissions are increased by construction or modification of a single machine. This would resnlt in extensive retrofitting obligations hardly consistent with the statutory emphasis on new emission sources. The statute sliould be ainended to uncouple the question of offset from the

87. 42 U.S.C. $\$ 7470$ (Supp. I 1979), referring to enhancement of air quality in national parks and other areas of special scenic, historic, or similar value.

88. H.R. ReP. No. 294, 95th Cong., lst Sess. 122, 127, 128, 132-33, 136, 146, reprinted in [1977] U.S. CODE CONG. \& AD. NEWs 1077, 1201, 1206-07, 1211, 1215, 1225.

89. 42 U.S.C. $\$ 7470(5)$ (Supp. I 1979).

90. Id. $\$ \S 7479(2)(\mathrm{C}), 7411(\mathrm{a})(4)$.

91. 44 Fed. Reg. 51,924, 51,931 (1979). 
other questions dependent upon the definition of "source," because the policies of the various provisions may require varying definitions.

\section{Administration}

Since the nondegradation program will be made a part of each state's implementation plan, the states will administer the permit program if they submit satisfactory plans; if they do not, the EPA will promulgate and administer its own under section $110(\mathrm{c})(1) .^{92}$ What is missmg is any provision for case-by-case federal review to ensure that the states do not issue permits im violation of the plan. The EPA is to be sent copies of permit applications, ${ }^{93}$ and the federal government has some say in the issuance of a permit for a facility that will affect certain federal lands, ${ }^{94}$ but no general veto power is provided as in the Federal Water Pollution Control Act.95 Once the permit is issued, both the EPA and any citizen may take action against violations of substantive requirements, ${ }^{96}$ but prevention is better than cure. ${ }^{97}$

Before issuance of a permit a "public hearing" must be "held with opportunity for interested persons . . . to appear and submit written or oral presentations . . . .98 The term "public hearing" often counotes the relatively informal "legislative" hearing commonly employed in general rulemaking, and the EPA so interprets it here; 99 but the issuance of a permit is an adjudicative matter often turning on facts peculiar to the applicant's facility. Due process probably entitles the applicant to a trial-type hearing under these circumstances, since a statutory riglit to a permit is created upon the satisfaction of prescribed conditions. ${ }^{100}$ Moreover, the Supreine Court has emphasized that the term "hearing" must be differently interpreted according to the context in which it is used. ${ }^{101}$ The courts should therefore liold that the word "public" serves to empliasize the right of the public to appear, not to

92. 42 U.S.C. $\$ 7410$ (c)(1) (Supp. I 1979).

93. Id. $\$ 7475(\mathrm{~d})(1)$.

94. Id. $\$ 7475$ (d)(2). See text accompanying notes $173-75$, 179-80 infra.

95. 33 U.S.C. § 1342 (Supp. I 1979).

96. 42 U.S.C. $\$ \$ 7413,7604$ (Supp. I 1979).

97. See Himes, supra note 9, at 697:

Any new legislation must create federal oversight over state implementation of the nondegradation policy. The same political pressures that prevented states from adopting effective nondegradation policies of their own will surely operate to subvert the protection of nationally valuable air resources when sucli protection conflicts with local interests.

98. 42 U.S.C. § 7475(a)(2) (Supp. I 1979).

99. See 40 C.F.R. $\S \S 51.24(\mathrm{r}), 52.21(\mathrm{r})$, added by 43 Fed. Reg. 26,387-88, 26,408-09 (1978).

100. For an extensive treatmeut of this topic, see Currie, Federal Standards for Mobile Sources of Air Pollution, 46 U. CHI. L. Rev. 811 (1980).

101. Florida E. Coast Ry. v. Umited States, 410 U.S. 224, 239 (1973). 
deprive the applicant of his probable constitutional riglt to a trial-type hearing.

\section{B. Best Available Technology}

One condition for issuance of a permit under section 165(a)(4), as under the prior regulations, is employment of "the best available control technology [BACT] for each pollutant subject to regulation under this chapter emitted from, or which results from, such facility."102 Technology requirements cannot prevent ultimate deterioration; even the best controls will allow degradation to the ambient standards if enough new sources are built. But the technology requirement serves to slow the pace of deterioration and thus to provide better air quality in the interim. Moreover, it serves the independent policy of rationing the limited assimilative resource that remains within the increments, helping to maximize the opportunity for additional growth. It also works to preserve the ultimate limits on ainbient concentrations. If the allocation were left entirely to the states, they might give the whole pie to the first comers and create irresistible pressures to relax the ambient limits themselves.

\section{Comparison with Other New-Source Requirements}

Section 111 already provided for the establishment of nationwide standards of perfornance for new sources based upon "the best system of emission reduction ... adequately demonstrated." 103 Section 169(3) provides that "best available control technology" for deterioration purposes shall "[i]n no event . . . result in emissions of any pollutants which will exceed the emissions allowed by any applicable standard established pursuant to [section 111 or 112]." 104 Thus, the requirements of sections 111 and 112 establish a minimum for major new sources in clean-air areas. The antideterioration provisions, however, impose in some cases a more onerous standard.

The insistence on a margimally stricter standard also appeared in the 1977 provisions for areas in which ambient standards are violated. Section 173 requires nnajor new sources in those areas to ineet "the lowest achievable emission rate," 105 which again may be more stringent than what is required under section $111 .^{106}$ Since every area is either

102. 42 U.S.C. $\& 7475(\mathrm{a})(4)$ (Supp. I 1979).

103. Id. $\$ 7411(\mathrm{a})(1),(1)(\mathrm{C})$.

104. Id. \& 7493(3). Section 112 deals with especially hazardous pollutants. Id. \& 7412 .

105. See § 173(2), codified at 42 U.S.C. \& 7503(2) (Supp. I 1979).

106. Section 171(3) provides that the term "lowest achievable emission rate" means "the most stringent emission limitation ... in the implementation plan of any State" (unless shown not achievable), or "the most stringent limitation . . . achieved in practice," whichever is more strin- 
an attainment or a nonattainment area for each pollutant and thus is subject to at least one of the stricter provisions, it would have made more sense to amend section 111 itself. ${ }^{107}$

There are numerous subtle differences in phrasing annong the various technological requirements that may reflect no substantive policy. For exaunple, section 111 was amended in 1977 to require "technological" controls and a "percentage reduction" in emissions in order to limit reliance on low-sulfur fuels; ${ }^{108}$ no comparable requirements appear in section 165. Moreover, "best available technology" under section 165 is defined as an "emission limitation," 109 and the Supreme Court held that the term as it appeared in section 111 did not include the prescription of work practices such as the wetting of asbestos before building demolition; ${ }^{110}$ the section 111 definition was broadened in 1977 , but section 165 contains the old, narrow language. Since section 165 standards are to be no less stringent than those under section 111, it is likely that these differences are attributable to oversight.

Section 165 , on the other hand, explicitly authorizes regulation of "production processes" and "innovative fuel counbustion techniques," which are not mentioned in section 173 and which appear in different terms in section 111 's definition of "technological" control systems. Finally, section 111 requires the "best system . . . adequately demonstrated," section 165 the "best available control technology," and section 173 the "lowest achievable emission rate." Perhaps all have the saine ineaning; an emission rate is not "achievable" unless the necessary technology is "available," and technology should probably not be held "available" or its expected emission level "achievable" unless it has been "adequately deinonstrated." Nevertheless, the use of three divergent formulas to express essentially the saine idea can only stimulate expensive and entirely unnecessary litigation.

Other differences annong the various new-source provisions clearly are deliberate. For exainple, while cost must be taken into account

gent, and that in no event shall the term permit emissions "in excess of the amount allowable under applicable new source standards of performance.” 42 U.S.C. § 7501(3) (Supp. I 1979).

107. See 43 Fed. Reg. 9452,9453 (1978), where the EPA in adopting $\$ 111$ standards for limenanufacturing plants warned that stricter requirements might apply in both attainment and nonattainment areas. Not every "major" source for purposes of $\$ \$ 111$ and 173 is "major" for PSD purposes ( $c f .42$ U.S.C. $\$ \S 7479(\mathrm{i}), 7602(\mathrm{j})$ (Supp. I 1979)), but the differences in coverage are rather trivial.

108. 42 U.S.C. $\& 7411$ (a)(1) (Supp. I 1979).

109. Hidden in $\S 302(\mathrm{k})$ is the definition of an "emission limitation," requiring reduction "on a contimuous basis" as in $\S 111.42$ U.S.C. $\S 7602(k)$ (Supp. I 1979). Both sections outlaw "interim" controls, i.e., turning the plant off in bad weather.

110. Adamo Wrecking v. United States, 434 U.S. 275 (1978). Thus, the EPA's attempt to provide for "design, equipment, work practice or operational" standards under $\S 165$, see 43 Fed. Reg. 26,388, 26,404 (1978) (adding 40 C.F.R. $\$ 52.21(\mathrm{~b})(10)$ ), may be doomed to failure. 
under all three sections, the formulas employed differ slightly, and the EPA has already taken the position that cost is entitled to less weight under section 173 than under section $111^{111}$ due to the importance of not exacerbating existing health hazards. Moreover, under section 169(3), the determination of "best available technology" for deterioration purposes is to be made "on a case-by-case basis," "12 which means it may be tighter in a particular case than would be acceptable in all attainment areas. Congress thus seems to have agreed with the Sierra Club's contention that reliance on the "lowest common denominator" of the nationwide new-source performance standards was "inconsistent with the policy of nondeterioration."113

Case-by-case determination, however, creates uncertainty in the planning stage and adds to the cost of processing applications. On its face, moreover, section 111 itself appears stringent enough that one would expect the air quahity benefits from atteinpting to squeeze even more out of section 165 would likely be ineager. However, the EPA has interpreted section 111 to permit a regulation requiring removal of only seventy percent of the sulfur dioxide generated by burning lowsulfur coal, despite the availability of technology for removing at least ninety percent. ${ }^{114}$ There is therefore apparently a margin for stricter PSD regulations at least in this context. ${ }^{115}$ Nevertheless, the importance of the added protection against deterioration afforded by individual determination of best technology is further reduced by the absolute ceilings on deterioration afforded by the independent limitation on increases in ambient concentrations. As the court said in accepting the EPA's reliance on section 111 standards to define best technology in its original regulations, "the use of a less effective emission reduction system by one new statutory source will simply use up more of the allowable increment and limit opportumities for other proposed new sources." 116 Case-by-case review of best technology may not in the last analysis be worth its cost.

It nakes perfect sense, however, for section 165 to require the best technology for sources that inay not be covered by section 111 standards, as required in the pre-1977 regulations. ${ }^{117}$ The problem of noninclusion should disappear as the EPA complies with the new statutory

111. 43 Fed. Reg. 9452, 9453 (1978).

112. 42 U.S.C. \$ 7479(3) (Supp. I 1979) (defining "best available technology").

I13. Sierra Club v. EPA, 540 F.2d at 1133-34.

114. 40 C.F.R. § 60.43(a)(1)(2), added by 44 Fed. Reg. 33,580, 33,614 (1979).

115. It has done so in the recent Colstrip case, see note 157 infra, but apparently in order to avoid violation of ambient increenents rather than as an individualized determination of "best available control technology."

116. Sierra Club v. EPA, 540 F.2d at 1133.

117. 40 C.F.R. $\S \S 52.21$ (d)(2)(ii), $52.01($ f) (1977). 
directive to adopt by $1982^{118}$ section 111 standards for all "major" sources-inore broadly defined than in section $165 .{ }^{119}$

\section{Pollutants For Which BACT is Required}

Every permittee is required to employ the best available control technology "for each pollutant subject to regulation under this chapter." 120 The EPA interprets this to mean "any pollutant regulated in Subchapter C of Title 40 of the Code of Federal Regulations for any source type." More precisely, this refers to any pollutant for which there are air quahty standards, new-source performance standards, hazardous pollutant limitations, or mobile-source standards, ${ }^{121}$ whether or not those standards apply to the source for which a permit is sought.

In one sense, every pollutant is "subject to regulation under this chapter," for "air pollutant" is all-inclusively defined, ${ }^{122}$ and newsource performance standards, for exainple, may be set for "any air pollutant." 123 As suggested above, ${ }^{124}$ however, such an imterpretation would render meaningless the qualifying words "subject to regulation under this chapter"; the EPA seems correct in interpreting them to mean pollutants subject to existing regulations. Moreover, while it may seein inappropriate for the technology requireinent to go beyond the provisions protecting ainbient levels, which it was ineant to help carry out, ${ }^{125}$ the statute refers to every pollutant regulated under this "chapter," not under this "part." The "chapter" is the entire Clean Air Act. ${ }^{126}$

Furthermore, the technology requirement does not seem to be limited to those pollutants emitted in sufficient quantities to trigger the permit requirement. Under the statute, a source emitting 100 (or 250) tons of "any air pollutant" is required to use the best controls for "each pollutant subject to regulation under this chapter." 127 If this means

118. 42 U.S.C. $\$ 7411$ (f)(1) (Supp. I 1979).

119. Id. $\$ 7602(\mathrm{j})$ (100 tons per year of any pollutant). Cf. id. $\$ 7479(1)$ (defining "major emitting facility" as used in $\S 165$ ).

120. Id. $\S 7475(\mathrm{a})(4)$. The definition of "best available control technology" repeats the quoted language. Id. \& 7479(3).

121. 43 Fed. Reg. at $26,397$.

122. 42 U.S.C. $\& 7602$ (g) (Supp. I 1979).

123. Id. \& 7411(a)(1).

124. See text accompanying notes 59-65 supra.

125. The pre-1977 regulations required BACT only for particulates and sulfur dioxide ( 40 C.F.R. $\$ 52.21$ (d)(2)(ii)), the pollutants for which ambient increments were establislied. 40 C.F.R. $\$ 52.21$ (c) (1977).

126. The Clean Air Act is codified as 42 U.S.C. ch. 85 "Air Pollution Prevention and Control."

127. A source which may emit 100 (or 250 ) tons of "any air pollutant" is a "major emitting facility," 42 U.S.C. $\& 7479$ (I) (Supp. I 1979), and therefore is subject to the requirements of $\& 7475$, including the BACT requirement, which apphes to each regulated pollutant. Id. § 7475(4). 
what it says, it seems most peculiar. A plant emitting 10 tons of particulates and nothing else is not subject to the control requirement; yet if it also emits 100 tons of sulfur oxides, it must control its particulates as well. The EPA rejected this interpretation, applying BACT and other requirements to a source "only with respect to those pollutants for which it would be a major stationary source or major modifica.tion" 128 and furtler dispensimg with BACT if "the increase in allowable emissions of that pollutant ... would be less than 50 tons per year." 129 Not only did this provision depart from the statute by substituting "allowable" for "potential" emissions and 50 tons for the statutory levels of 100 and 250; but also careless statutory drafting has proscribed the EPA's sensible premise that BACT should be required only for those pollutants of which the source is a "major" one. The EPA's imterpretation has been rejected by the District of Columbia Circuit. $^{130}$

\section{Ambient Increments for Sulfur Dioxide and Particulates}

The best-technology requirement helps to apportion the limited assimilative capacity of the air and to postpone the date of degradation to the ambient standards. It could not, lowever, prevent sucli degradation in the long run, even if it covered all new sources. Thus, to enforce tle antideterioration requirement of section 161, section 163(b) prescribes in micrograms per cubic meter "the maximum allowable increase in concentrations of sulfur dioxide and particulate matter over the basehine concentration," "131 which section 169(4) defines (with an adjustment for plants wliose construction began before January 6 , 1975) as "the ambient concentration levels which exist at the time of the first application for a permit in an area subject to this part. . . ."132 With an exception discussed below, ${ }^{133}$ the applicant for a permit must sliow that this new source "will not cause, or contribute to, air pollution in excess of any . . . maximum allowable increase . . . for any pollutant in any area to which this part applies unore than one time per year."134 Section 163(a) rcquires that cach state plan contain measures to protect against violation of the section $163(\mathrm{~b})$ limitations by smaller

128. 43 Fed. Reg. 26,385 (1978) (adding 40 C.F.R. § 51.24(i)(1)); 43 Fed. Reg. 26,406 (1978) (adding 40 C.F.R. $\$ 52.21(i)(1)$ ).

129. 40 C.F.R. $\$ \S 52.21(\mathrm{j})(2), 51.24(\mathrm{j})(2)$.

130. Alabama Power Co. v. Costle, 606 F.2d at 1086; 13 E.R.C. at $2045-47$.

131. 42 U.S.C. $\$ 7473$ (b) (Supp. I 1979).

132. Id. $\$ 7479(4)$. This definition unfortunately means that deterioration resulting from any number of small new sources constructed before the first application for a inajor-source permit will not be counted. The justification must be to avoid the administrative cost of modeling until sucl an application is made. See Alabama Power, 13 E.R.C. at 2020-22.

133. See text accompanying notes 171-77 infra.

134. 42 U.S.C. $\$ 7475(a)$ (3) (Supp. I 1979). 
sources. The net effect of these ceilings or "increments" is to fix air quality standards inore stringent than those set under section 109, varying according to existing air quahty.

The arbitrariness of this approach is apparent; future air quahty is to be determined not by weighing the competing costs of pollution and its cures but by the accident of past development. Those areas that happen to be cleanest today may not be those we think it most important to have clean. Moreover, by imposing limitations based on current ambient conditions in all clean areas the statute promotes the dispersion of new sources, which may make it more difficult to preserve those areas inost deserving protection. Closer inspection may help in evaluatimg these concerns.

\section{Area Classification}

Section 163(b), like the earlier regulations, responds to the danger of uniform dispersion by creating three distimct land classifications subject to different incremental limits. ${ }^{135}$ Annual sulfur dioxide concentration, for example, may not increase by more than two micrograms per cubic meter in class I areas, twenty in class II, and forty im class III..$^{136}$

The class II and III increments were taken from the House bill. ${ }^{137}$ The House Committee, quoting an EPA-Federal Energy Admmistration (FEA) analysis, explained in some detail what it thought they would mean for future development. Taking coal-fired power plants as most likely to be affected by the increments because of their large emissions, the committee concluded that "[n]ew coal-fired power plants as large as 250 percent the size of the largest existing plants could be built in a class II area," as could "any of 19 major industrial sources regulated by EPA (except a new grass roots steel mill-none of which are planned)." Additional large power plants, the EPA added, could be built in class II areas at fourteen-mile intervals, assuming high-sulfur coal with ninety percent flue-gas desulfurization, which the new-source performance standards independently require. ${ }^{138}$ If these predictions prove accurate, class II designation should not be a significant impediment to industrial development, ${ }^{139}$ although it may require greater spacing of facilities within the area than would otherwise be under-

135. Id. $\S 7463(\mathrm{a})$.

136. Id. $\$ 7473(\mathrm{~b})$. The corresponding particulate matter figures are 5,19 , and 37 respectively. There are also 24-hour and, in case of sulfur, 3-hour maxima to prevent harm due to shortterm deterioration. The particulate concentrations are geometric means, the sulfur arithmetic. Id.

137. See H.R. ReP. No. 564, 95th Cong., Ist Sess. 151, reprinted in [1977] U.S. Code CoNG. \& AD. NEWS 1502, 1532.

138. Id. at 154-55, 160-61, reprinted in [1977] U.S. CODE CONG. \& AD. NEws 1077, 1233-34, $1239-40$.

139. Id. at 162-64, reprinted in.[1977] U.S. Code Cong. \& AD. News 1241-43. 
taken; and the class III increments, generally less stringent by a factor of two, permit even greater development. Indeed, these increments are lenient enough to suggest that they were chosen with the intention of minimizing interference with growth; the House Committee stressed that its proposal reflected "a balanced approach not only protecting public health and welfare but also assuring future air resources will be available for continuing the industrial and energy development so necessary for the growth of the Nation."140

The class I increments, on the other hand, permit very hittle degradation. The House Committee, discussing proposed mcreinents approximating those in the statute as adopted, acknowledged that "huge, new, coal-fired powerplants and other similar heavily polluting industries" would not be allowed in or immediately adjacent to class I areas. $^{141}$ It is here that nondegradation has its inost significant impact.

Everything turns, in other words, on whether an area is designated class $I$. If it is, it must remain very nearly as it has been; if it is not, it niay experience more or less norunal development, at the price of installing first-rate controls.

\section{Class I Areas}

Section 162(a) specifies that the following "shall be class I areas and may not be redesignated": "all-(1) imternational parks, (2) national wilderness areas which exceed 5,000 acres im size, (3) national memorial parks which exceed 5,000 acres in size, and (4) national parks which exceed six thousand acres in size, and which are in existence on August 7, $1977 \ldots . .142$

This list was taken from the Senate bill;"143 its purpose was "to provide additional protection for air quality in areas where the Federal Government has a special stewardship to protect the natural values of a national resource."144 This principle makes eminent sense. Even if no objective harm could be shown from contaminants at levels below am-

140. Id. at 154, reprinted in [1977] U.S. CODE CONG. \& AD. NEws 1077, 1233. The House Committee's conclusions as to the effect of the class 11 increments, however, are seriously challenged in Note, Prevention of Significant Deterioration of Air Quality: The Clean Air Act Amendments of 1977 and Utah's Power Generating Industry, 1977 UTAH L. REv. 775.

The Honse Report, according to this commentary, assumed flat terrain and favorable ineteorological conditions; insistence on ineeting class II increments im a canyon meant that one power plant would have to be built at a site less enviroumentally desirable overall; strict adherence to the class II requirement would be a serious obstacle to future power plant construction in Utah.

141. H.R. REP. No. 294, 95th Cong., 1st Sess. 156-57, reprinted in [1977] U.S. CoDE CoNG. \& AD. NEws 1077, 1235-36.

142. 42 U.S.C. $\$ 7462$ (a) (Supp. I 1979).

143. See H.R. REP. No. 564, 95th Cong., 1st Sess. 152, reprinted in [1977] U.S. CodE CoNG. \& AD. NEwS 1502, 1532.

144. S. REP. No. 127, 95th Cong., 1st Sess. 34 (1977). 
bient standards, the unspoiled condition of these areas is one of their most prized values. Strict antideterioration requirements serve to carry out the purpose for which national parks were established, which according to statute is "to conserve the scenery and the natural and historic objects and the wild life therein and to provide for the enjoyment of the sanne in such manner and by such means as will leave them unimpaired for the enjoyment of future generations." 145 As the House Committee said, "it was not the intent of Congress to pass legislation preserving areas such as the Grand Canyon, Yellowstone, the Everglades and other unique national treasures and then to permit the air quality to deteriorate to levels similar to those reached in some of our major industrial cities." 146 Moreover, there were authoritative predictions that strict limits were necessary to prevent serious and objective injury to park values: "EPA analysis shows that . . . allowing class II air pollution levels in national parks on 18 days per year would reduce visibility in areas such as the Grand Canyon by up to 75 percent."147 So long as there are other places that industrial development can reasonably take place, it follows from the very establishment of parks and wilderness areas that they should be given special protection against impairment of air quality. And since many of the protected areas enjoy reasonably uncontaminated air today, incrennents over existing quality may provide for thein a more accurate reflection of variations in natural background levels than would a uniform "pristine" air quahity standard. ${ }^{148}$

If the only effect of class I designation were to limit development within the designated area, criticism of the mandatory class I list would be muted; large national parks and wilderness areas, as the House Report said of other protected lands, "are not generally open for the siting of large industrial facilities" in any case. ${ }^{149}$ The pmch, however, is due to the fact that in order to protect such areas there must be limits on development in adjoining areas. Under section 163(a), the implementation plan must "assur[e] that maximum allowable increases . . . not be exceeded," 150 meaning anywhere; under section 165(a)(3), a permit applicant must slow that his emissions "will not cause, or contribute to air pollution in excess of any . . . maximuin allowable increase . . . for

145. 16 U.S.C. $\& 1$ (1976).

146. H.R. REP. No. 294, 95 th Cong., 1st Sess. 148, reprinted in [1977] U.S. Code CONG. \& AD. News 1077, 1227. See also Hines, supra note 9, at 649.

147. H.R. Rep. No. 294, 95th Cong., 1st Sess. 159, reprinted in [1977] U.S. Code Cong. \& AD. News 1077, 1238.

148. See S. Rep. No. 127, 95th Cong., 1st Sess. 30 (1977).

149. H.R. ReP. No. 294, 95th Cong., 1st Sess. 157, reprinted in [1977] U.S. CoDE Cong. \& AD. NEwS 1077, 1236.

150. 42 U.S.C. \& 7473(a) (Supp. I 1979). 
any pollutant in any area to which this part applies . . ."151 It was the fear that large buffer zones would be set up around class I areas that prompted the United States Chamber of Commerce to protest that the House bill "would inake at least 70 to 80 percent of the land areas of most States off limits to any new developinent,"152 which would be a sobering price to pay for wilderness preservation.

The House Committee, however, thought the Chamber's assumption of fifty- to sixty-mile buffer zones was unreasonably excessive: According to joint FEA-EPA calculations, [a] well-controlled 1,000 megawatt powerplant, one of the largest stationary sources of air pollution could locate as close as three miles [to a class I area], depending upon conditions specific to the site. Other major industrial sources, with lesser emissions, could locate even closer. ${ }^{153}$

The Committee concluded that under the House bill [p]rotection of the relatively few Federal class I areas would preclude the siting of very large, heavily polluting industrial plants on only 4 to 5 percent of the Nation's total land area. Most of that land is within national forests, national wildlife refuges, et cetera, already restricted from heavy industrial use . . . . 154

The mandatory class I areas are more extensive under the statute than under the House bill since the minimum acreage requirements were dropped froin $25,000^{155}$ to 5,000 and 6,000 acres, respectively. But if the EPA and FEA were right that enormous power plants could be located within a few miles of class I areas, ${ }^{156}$ the sacrifice does not seem to outweigh the benefits of park preservation. ${ }^{157}$

151. Id. \$7475(a)(3). See also id. \$7475(d)(2)(A), (d)(2)(C)(i).

152. See H.R. REP. No. 294, 95th Cong., 1st Sess. 157, reprinted in [1977] U.S. CodE CoNG. \& AD. NEws 1077, 1236.

153. Id. at 158, reprinted in [1977] U.S. CODE CONG. \& AD. NEws 1237.

154. Id. at 154, reprinted in [1977] U.S. CODE CONG. \& AD. NEws 1233.

155. Id. at 398; 42 U.S.C. \& 7472(c) (Supp. I 1979).

156. The House Committee recognized that the distance that would have to separate a major industrial facility from a class I area would depend on a number of factors, including size of the source, type of fuel burned, type of pollution control equipment, and the meteorology and terrain of the area. H.R. REP. No. 294, 95th Cong., 1st Sess. 158, reprinted in [1977] U.S. CODE CoNG. \& AD. News 1077, 1237.

157. Industry made much of the denial of a permit for new generating units at the Colstrip power statiou in Montana. In August 1977, under the old regulations, the EPA redesignated the Northern Cheyenne Indian Reservation to class I at the request of its governing body, 42 Fed. Reg. 40,695-96 (1977), acknowledging that this classification would require $90 \%$ reduction of sulfur dioxide emissions from the proposed Colstrip units despite their use of low-sulfur coal. A year later the EPA denied a permit for the new Colstrip units on the ground that their emissions would violate class I sulfur dioxide increments on the Reservation. 43 Fed. Reg. 36,322 (1978). A variance under $\$ 165(d)(2)(D)$ was refused because that provision applies only to federal and not to Indian lands. See [1978] 9 ENvir. ReP. (BNA) 661-62. The EPA suggested, however, that a new permit application be submitted under § 164(e), codifed at 42 U.S.C. § 7474(e) (Supp. I 1979), which somewhat vaguely authorizes the EPA not only to resolve disputes between states and tribes over the classification of Indian land, but also to "resolve . . . disputes" when a tribe determines that a requested permit would offend the increments. See [1978] 9 ENVIR. REP. (BNA) 661-62. 
Yet to say that large plants can be built within a few miles of class I areas is not to say that it can be done at an acceptable cost. On the cost question the House Report is considerably less specific. It assumes the use of BACT,,$^{158}$ and states that the cost of the entire BACT package to the electric consumer will be no more than one or two dollars per month. ${ }^{159}$ The amount sounds trivial, but doubtless this manner of expression was chosen because the total sum to be expended would sound enormous. Moreover, no attempt was made to identify that portion of the cost attributable to the class I limits themselves. Intelligent evaluation of the price tag for park protection must await additional information.

Equally serious is the opposite question whether the statute provides protection for enough scenic areas. Not only are parks and wilderness areas of less than 6,000 and 5,000 acres, respectively, excluded from the mandatory class I category; but also national forests and wildlife refuges are not mentioned, and the Senate Report stresses that "[t]he reference to national parks is only to those lands denominated as 'national parks,' not to all elements of the National Park System."160 National seashores, national monuments, and scenic rivers, all of which may require pristime air for full enjoyment, are not included. Fimally, the designation apphies only to parks and wilderness areas "im existence on August 7, 1977." 161

This does not preclude class I protection for the omitted areas; section 162(a) designates as class I "[a]11 areas which were redesignated as class I under regulations promulgated before August 7, 1977,"162 and under section 164(a) any area may be redesignated as class $I$ in the future. ${ }^{163}$ However, class I areas other than the large parks and wilderness areas listed in section 162(a) may be redesignated as class II, or, with some exceptions, as class III under section 164(a); ${ }^{164}$ and redesig-

Following negotiations between the company and the tribe, the company agreed among other things to reduce sulfur dioxide by 95 percent, and the permit was granted. See [1979] 10 ENVIR. REP. (BNA) 1189, 1277-78. Thus, the PSD requirements have not prevented construction of this major facility in the neighborhood of a class I area. Moreover, even if the permit resulted from a relaxation of the applicable increments under the limited provisions of \& 164(e), see note 175 infra, the fact that one proposed plant required sucli a relaxation does not demonstrate that the standards leave too little room for development.

158. H.R. REP. No. 294, 95th Cong., Ist Sess. 158, reprinted in [1977] U.S. Code CoNo. \& AD. NEws 1077, 1237.

159. Id. at 164, reprinted in [1977] U.S. CoDE Cong. \& AD. News 1243.

160. S. REP. No. 127, 95th Cong., Ist Sess. 34 (1977). See also note 144 and accompanying text supra.

16I. 42 U.S.C. § 7472(a) (Supp. I 1979).

162. Id.

163. Id. \& 7474(a).

164. Id. \& 162(a), codiffed at 42 U.S.C. \& 7472(a) (Supp. I 1979).

[A] national monument, a national primitive area, a national preserve, a national recrea- 
nation in either direction is at the whim of the state or, in the case of Indian reservations, at that of "the appropriate Indian governing body." 165 No federal agency has authority to designate federal lands as class I or to prevent their placement in a lower classification, except that the EPA Administrator inay disapprove a redesignation for failure to comply with "procedural requirements"166 or with the limitations already mentioned. ${ }^{167}$

The reluctance of Congress to require that all federal nature preserves be given class I protection is understandable, simce it is difficult for Congress to balance the competimg considerations for a myriad of different situations. The refusal to give the EPA authority to protect these federal lands, however, seems to constitute an abdication of federal responsibility, ${ }^{168}$ particularly in view of the House Committee's recognition that protection is inherent in the establishment of scemic areas. ${ }^{169}$ To set up a complicated federal program to protect the air in scenic areas and then to allow states to undermine it by allowing pollution to reach levels that "would reduce visibility . . . by up to 75 percent"170 is a cruel pretense; the states would have had the same option to provide protection without the aid of hollow federal verbiage. Except for the limited list of mandatory class I areas, the statute fails to provide adequate security for areas requiring special protection.

Moreover, even the protection afforded mandatory class I areas is inadequate. Section 165(d)(2)(C)(iii) allows a state to issue a permit for a major emitting facility "notwithstanding the fact that the change in air quality resulting from emissions from such facility will cause or contribute to concentrations which exceed the maximum allowable increases for class I areas" if the manager of the affected federal lands "certifies . . . that the emissions . . . will have no adverse impact on the air quality-related values of such lands (including visibility)."171 The basic outer limit in such cases is the class II increments for sulfur dioxide and particulates. ${ }^{172}$ If the Federal Land Manager balks and

tional area, a national wild and scenic river, a national wildlife refuge, a national lakeshore or seashore, and (2) a national park or natioual wilderness area established after August 7, 1977 may not be redesignated as class III if it exceeds ten thousand acres in size.

42 U.S.C. $\$ 7474(a)$ (Supp. I 1979).

165. Id. $\$ 7474(\mathrm{a})$, (c).

166. Chiefly public hearing, impact analysis, consultation with managers of affected federal lands, and a statement of reasons for disagreement with federal recommendations. Id. $\S 7474(\mathrm{~b})(1)$.

167. Id. $\S 7474(\mathrm{~b})(2)$.

168. See Himes, supra note 9, at 695, 701.

169. See text accompanying notes $145-46$ supra.

170. See note 147 supra.

171. 42 U.S.C. $\$ 7475$ (d)(2)(C)(iii) (Supp. I 1979).

172. Sulfur dioxide has a somewhat tighter three-hour level. See id. $\$ 7475$ (d)(2)(C)(iv). 
the Governor finds that a variance from class I three-hour and/or twenty-four-hour sulfur dioxide standards is needed to allow construction of the facility and will have no adverse effect, the President may allow it "if he finds that such variance is in the national interest," and "[n]o Presidential finding shall be reviewable im any court." A Presidential variance, however, may only allow the class $I$ increments to be exceeded eighteen days per year, subject to sulfur dioxide levels considerably below class II standards. ${ }^{173}$

In sum, section 165(d) fails to assure that the class I increments will not be exceeded im mandatory class I areas. The House Committee had recommended against a variance provision, arguing that "class II air pollution in national parks on 18 days per year," as section 165(d) permits the Land Manager to allow, "would reduce visibility in areas such as the Grand Canyon by up to 75 percent." It also noted the EPA's argument that modeling techniques were insufficient to admimister variances, and described the provision as "a special interest proposal" designed to accommodate a single projected power plant whose sponsors admitted it could be built at a nearby site without a variance. ${ }^{174}$ While section 165 (d) does attempt to obviate the first objection by requiring either that the Land Manager find no adverse impact or that the variance be limited to sulfur levels short of class II, it weakens the statutory protection of the parks. The focus on "adverse impact" suggests a possible departure from the salutary principle un-

173. Id. $\$ 7475(\mathrm{~d})(2)(\mathrm{D})$. These provisions contain a few ambiguities. Although vesting authority in the President suggests a congressional desire that the decision not be inade by the EPA, the statute does not explicitly say, as does $\$ 110(\mathrm{f})(1)$, codified at 42 U.S.C. $\$ 7410(\mathrm{f})(1)$, with regard to energy emergencies, that the President's power may not be delegated. Absent a clear indication to the contrary, courts generally allow delegation. See, e.g., Wilcox v. McConnel, 38 U.S. (13 Pet.) 498, 513 (1839). Moreover, all that is inade immune from judicial review is a "Presidential finding," and this phrase follows the specification that the President "[find] that such variance is in the national interest." The aim seems to be to give him total discretion to decide whether a variance should be granted, but not to ignore explicit statutory hinits on the increments of pollution the variance may allow. Precedent suggests, despite legislative history that "[t]he President's decision is a final, nonreviewable decision," H.R. REP. No. 564, 95th Cong., 1st Sess. 153, reprinted in [1977] U.S. CODE CONG. \& AD. NEws 1502, 1534, that the courts will not construe "finding" to include every aspect of the variance. See, e.g., Johnson v. Robison, 415 U.S. 361 (1974).

Similarly, it is unclear whether the decision of the Federal Land Manager that there will be "no adverse impact on air quality-related values" is subject to judicial review. When the state issues the permit, presumably its action will be reviewable in state court; the question is whether federal law commits the determination of "adverse inpact" to the unfettered discretion of the Manager. The statute reads as though it does; the permit will be granted not if there will be no adverse effect but only if the Manager "so certifies," and if the matter is "demonstrate[d]" to his "satisfaction." However, the courts have found less discretion than ineets the eye in other provisions of the Clean Air Act, see Natural Resources Defense Council v. Train, 545 F.2d 320 (2d Cir. 1976); the matter is not free froin doubt.

174. H.R. ReP. No. 294, 95th Cong., 1st Sess. 158-59, reprinted in [1977] U.S. CodE CoNo. \& AD. News 1077, 1237-38. 
derlying class I increments that purity is a value in itself in scenic areas; the Land Manager seems to be given too much discretion to compromise the interests of users. Moreover, there is no requirement that alternative sites be shown substantially less desirable. Although the statute should contam a general provision allowing variances for unreasonable hardship, section 165 (d) seems to go too far. ${ }^{175}$

Furthermore, although the annual class I imcrements of two and five micrograms per cubic meter look insignificant on their face, ${ }^{176}$ the House Report recounted testimony that "even meeting the class I increnients, up to a 40-percent reduction in visual range could result." I77 If accurate, this testimony suggests that serious consideration should have been given to further limitations upon permissible increments.

To provide additional protection, however, Congress instituted two inore safeguards. First, as discussed below, ${ }^{178}$ it enacted a new subpart designed specifically to protect visibility in mandatory class I areas. Second, in section 165(d)(2)(C)(ii) it extended the case-by-case approach of the variance provision to the converse situation. If the Federal Land Manager "demonstrates to the satisfaction of the State" that concentrations not violating the increments "will have an adverse mipact on . . . air quahity-related values (including visibility)" in a class I area, "a permit shall not be issued." 179 While the "satisfaction of the State" terminology might hint that the matter is within the dis-

175. Furthermore, the Colstrip controversy described in note 157 supra suggests the possibility that § 164(e) may be construed to provide an additional mecbanism for allowing the statutory class I increments to be exceeded under certain circumstances. If "the Governor of an affected State or governing body of an affected Indian tribe determines" that a proposed permit will cause a violation of the increments, the Administrator upon request by the state or tribe "shall make a recommendation to resolve the dispute and protect the air quatity related values of the lands involved." If the parties do not agree, he "shall resolve the dispute," and his resolution becomes part of the implementation plan. 42 U.S.C. § 7474(e) (Supp. I 1979). In reporting the EPA's letter informing the power company it might reapply under $\& 164(\mathrm{e})$, one commentator stated that " $[t]$ he section authorizes the administrator to allow excesses of the applicable increments . . . ." [1978] 9 ENVIR. REP. (BNA) 662. Section 164(e) certainly does not say this in so many words; the "dispute" it empowers the Administrator to "resolve" might as easily be over whether the state or tribe is correct in determining that the new facility would offend the imcrements, and to "protect the air quality related values" may mean to enforce the imcrements. A reading of $\$ 164(\mathrm{e})$ as authorizing variances is not easy to reconcile with the flat command of $\S 165(\mathrm{a})(3)(\mathrm{A})$ that no permit be issued in violation of the imcrements, simce, unlike the express variance provisions of $\S 165(\mathrm{~d})(2)(\mathrm{C})$ and (D), it does not explicitly authorize the issuance of a permit not meeting the ordinary requirements.

176. See Currie, supra note 7; Currie, Enforcement under the Illinois Pollution Law, 70 Nw. U.L. REv. 389 (1975).

177. H.R. REP. No. 294, 95th Cong., 1st Sess. 205, reprinted in [1977] U.S. CODE CONG. \& AD. NEws 1077,1284 . Whether the imcrements in question were identical to those in the statute as adopted is uncertain; but the statutory class I increments track those of the prior regulations, and those in the House Committee bill were in the same range.

178. See Part II infra.

179. 42 U.S.C. $\$ 7475$ (d)(2)(C)(ii) (Supp. I 1979). 
cretion of the state agency, suclı a holding would deprive the explicit mandate that the permit "shall not" be issued of its force; precedent suggests the determination is reviewable. ${ }^{180}$ The effect is to create a general statutory prohibition on new major emitting facilities having adverse effects on class I areas. If the availability of satisfactory alternative sites can be predicted with confidence, this may well be a sound provision.

Perhaps the inost significant, and inost desirable, feature of section 165(d)(2)(C)(ii) is that it does not appear to be limited to pollutants for which numerical imcrements have been established. ${ }^{181}$ Its very existence testifies that Cougress appreciated the impossibility of protecting agamst all harm by numerical regulations, and the unregulated harm most likely to occur is the harm precipitated by unregulated pollutants.

\section{PSD in Nonscenic Areas}

While the statute seens to give inadequate protection to scenic areas in which any deterioration inay be significant, Congress deliberately rejected the provision of the prestatutory regulations allowing degradation to the aunbient standards in class III areas. ${ }^{182}$

If it is assumed that existing air quahty standards fulfill their statutory mandate "to protect the public health" and "to protect the public welfare from any known or anticipated adverse effects," 183 then the universal application of nondegradation increnents seens monsensical. If the standards are adequate to prevent harm in the absence of special scenic values, full utilization of the assimilative capacity they define can be permitted without significant cost. Indeed, by givmg maximunn freedom for development in nonscenic areas consistent with avoidance of mjury, maximuin protection is afforded to the scenic areas of highest preservation priority. Better a power plant in a barren desert than next door to Yellowstone Park; the more we discourage construction in wastelands the more pressure we create for contpromising our parks.

The principal case for limited class III increments is a profound dissatisfaction witl the existing air quality standards. "Since 1971

180. See note 175 supra. In Natural Resources Defense Council v. Train, 545 F.2d 320 (2d Cir. 1976), the court held that the Administrator had no discretion to refuse to institute the process of setting ambient standards for lead after finding it produced by numerous sources in dangerous concentrations despite the fact that $\S 108$ directs him to do so only for those pollutants "for which he plans to issue air quality criteria . . . ." 42 U.S.C. $\$ 7408(a)(1)(C)$ (Supp. I 1979).

181. The statute requires that "the emissions" from a facility subject to the permit requirement be found to have an adverse impact, not the emission only of certain pollutants. Accord, Tundermann, Protecting Visibility: Key to Preventing Significant Deterioration in Western Air Quality, 11 NAT. Resources LAw. 373, 377 (1978).

182. See S. ReP. No. 127, 95th Cong., 1st Sess. 34 (1977).

183. 42 U.S.C. $\$ 7409$ (b)(1), (2) (Supp. 1 1979). 
when the national ambient air quality standards were set," the House Report stated, "new and disturbing information has come to light showing that the public's health is being harmed to soine extent, perhaps seriously, even at levels below the national standards." 184 This conclusion is documented in soine twenty-four pages of the report, ${ }^{185}$ and similar conclusions are drawn as to secondary standards designed to protect public welfare froin other adverse effects. ${ }^{186}$ The logical response to these findings would be to set stricter standards, as the statute requires. ${ }^{187}$ Freezing ambient quahty within prescribed increments above existing levels is a poor substitute, too strict in soine areas and not strict enough in others; if sixty micrograms per cubic meter is the threshold of harm, it is not optimal to allow only twenty in Fargo and eighty in Duluth.

Existing levels, however, are suggestive of the cost of achieving a harmless concentration. In general, it may be cheaper to disperse new sources than to backfit old ones with better controls. Cost-benefit comparisons therefore inay justify requiring somewhat better air quality in regions that are still clean, though to do so departs from the statutory principle that all harm nust be prevented regardless of cost. More fundamentally, the House Report reflects a mistrust of the entire notion of harmless concentrations that underlies ambient standards. Harm cannot be eliminated with certainty without setting the standards at zero. ${ }^{188}$ Thus, even if the ambient standards themselves are tightened to satisfy new findings concerning harmful levels, pollution should be kept as far below these levels as it reasonably can be, and it reasonably can be kept lower in areas that are now clean than elsewhere. ${ }^{189}$

The House Committee Report put the case for nationwide nondegradation rather strongly. If the Committee is correct in assuming that the increments for classes II and III will not materially impede development, the decision may be a supportable precaution in light of inadequate knowledge of health effects. But once again one inust lament the insufficiency of hard cost information in the House Report.

184. H.R. REP. No. 294, 95th Cong., 1st Sess. 106, reprinted in [1977] U.S. CODE CoNG. \& AD. NEwS 1077, 1184.

185. Id. at 10S-27, reprinted in [1977] U.S. CODE CONG. \& AD. NEws 1183-1206.

186. Id. at 127-35, reprinted in [1977] U.S. CODE CONG. \& AD. NEwS 1205-14.

187. 42 U.S.C. \& 7409(d)(1) (Supp. I 1979).

188. H.R. ReP. No. 294, 95th Cong., 1st Sess. 110-12, reprinted in [1977] U.S. CoDE CoNG. \& AD. News 1077, 1188-91.

189. The House Committee also argued for PSD as a means of preventing the economic disruption that might be caused by a flight of industry away from areas not ineeting ambient standards. Id. at 133-35, reprinted in [1977] U.S. CODE CONG. \& AD. NEws 1211-14. Increments applicable everywhere without regard to the harm done by pollution help to promote this purpose, but there must be better ways of protecting the vietims of departing industry than by requiring large expenditures to control "pollution" that is assumed to be harmless. 
To say that the domestic consumer of electricity will pay a dollar or two per month for the whole PSD program ${ }^{190}$ is not to prove that the insurance the class II and III increments provide agamst unknown dangers is worth the price.

\section{Other Pollutants}

Like the earlier regulations, section 163 prescribes ambient increments only for particulates and sulfur oxides. ${ }^{191}$ The EPA had justified its omission of increments for hydrocarbons, oxidants, and nitrogen oxides on the ground that ineasuring and predictive techniques did not permit sufficiently accurate assessment of the impact of emissions upon air quality in light of complex photochemical reactions. Moreover, observing that these pollutants as well as carbon monoxide come in substantial part from vehicles, the EPA concluded that existimg provisions respecting vehicle emissions were "adequate to prevent any significant deterioration due to sources of carbon monoxide, liydrocarbons or mtrogen oxidcs." ${ }^{192}$ Less certam of the latter conclusion, Congress in section 166(a) required the EPA to promulgate regulations by August 7, 1979 , to prevent significant deterioration resultimg from hydrocarbons, carbon inonoxide, photochemical oxidants, and nitrogen oxides. ${ }^{193}$ Regulations respecting additional pollutants are to be adopted within two years after ambient standards are proinulgated. ${ }^{194}$ The regulations adopted under section 166(a) need not provide for either ambient imcrements or area classification but must contam "specific numerical 1neasures against which permit applications may be evaluated" and "specific ineasures at least as effective as the increments established in section 163 " in accomplishing the statutory purposes. ${ }^{195}$

How suitable plans will be developed under these flexible provisions remains to be seen. For automotive pollutants the most obvious strategy is the so-called "indirect source" approach earlier developed in counection with ambient air quality standards. Central to this approach is the requirement of a permit for construction of any facility, such as a shopping center, that would contribute indirectly to air pollution by attracting notor vehicles. The critical condition for permit issuance is that vehicles using the new facility not cause a violation of the applicable standard, ${ }^{196}$ or, in the case of PSD, a violation of the applicable air quality increment.

190. Id. at 164, reprinted in [1977] U.S. CODE CONG. \& AD. NEwS 1243.

191. 42 U.S.C. \& 7473 (Supp. I 1979).

192. See 39 Fed. Reg. 31,006 (1974).

193. The EPA missed this deadline.

194. 42 U.S.C. \& 7476(a) (Supp. I 1979).

195. Id. $\$ \$ 7476(\mathrm{e})$, (c), (d) (Supp. I 1979).

196. 40 C.F.R. $\& 52.22$ (1974). 
Widespread objections, however, led Congress in 1977 to sharply limit the EPA's authority to impose indirect-source review programs, leaving the states free to adopt such provisions voluntarily. ${ }^{197}$ But section $110(a)(5)(D)$ defines an indirect-source review program as "facility-by-facility review of indirect sources of air pollution, including such ineasures as are necessary" to avoid violations of an "ainbient air quality standard." 198 Arguably this means the EPA Administrator himself inay require indirect-source review for purposes of avoiding significant deterioration rather than violation of ambient standards. Given the strong congressional antipathy to federally required indirect-source review and the ordinary ineaning of the statutory term, however, it seeins probable that a court would hold the clause "including . . . measures" to meet ambient standards as illustrating rather than limiting the scope of "facility-by-facility review."

II

\section{VisIBILITY PROTECTION}

Section $110(a)(2)(J)$, as noted above, requires implementation plans to ineet the requirements of "part C"; that part contains not only the nondegradation provisions discussed above but also special provisions for protecting visibility in areas categorized permanently for nondegradation purposes as class I. Those areas are the large national parks and wilderness areas that Congress reasonably thought deserving of special protection.

Section 169A(a)(1) "declares as a national goal the prevention of any future, and the remedying of any existing, impairment of visibility in inandatory class I Federal areas" resulting from "manmade air pollution." 199 EPA regulations are to require "reasonable progress toward ineeting the national goal," ${ }^{200}$ considering annong other things "the cost of compliance."201 Under section 169A(b)(2) the regulations inust, ainong other things, specifically require impleinentation plans to insist upon the installation and use, in not more than five years, ${ }^{202}$ of "the best available retrofit technology" for any existing "inajor stationary source," not more than fifteen years old, emitting "any air pollutant which may reasonably be anticipated to cause or contribute to any impairment of visibility in any such area." 203

197. 42 U.S.C. $\& 7410(\mathrm{a})(5)$ (Supp. I 1979).

198. Id. $\$ 7410(\mathrm{a})(5)(\mathrm{D})$.

199. Id. \& 7491(a)(1).

200. Id. \& 7491(a)(4).

201. Id. \& 7491(g)(1).

202. Id. $\$ 7491(\mathrm{~g})(4)$.

203. Id. \& 7491(b)(2)(A). 
The goal is admirable, the means cautious; "best available retrofit technology" is to be determined with comphance costs im mind. ${ }^{204}$ "Reasonable progress" may in some cases require the shutdown of old plants that cannot avoid impairing visibility even with such technology, and the retrofitting of sources that are not "major."205 The exemption of plants more than fifteen years old is an apparent concession to their relatively brief remaining life. That they need not be made subject to the retrofit requirement does not on its face seem to protect them from retrofit or other regulations, mcludimg shutdown, determined to assure "reasonable progress"; yet, the House Report flatly stated that "the administration may not require States to apply the best retrofit technology to sources which have been im existence more than 15 years."206

The EPA Administrator is authorized, with the concurrence of the Federal Land Manager, to exempt any source from the retrofit requirement on a showing that its foreseeable impairment of visibility will not be "significant."207 The House Report stated the purpose was "to permit exemption for smaller, isolated sources which make an insignificant contribution to visibility impairnent and to make clear that no such retrofit would be required for sources im the vicinity of areas, such as the Smoky Mountains."208 Evidently the Report intended to add something about areas with naturally poor visibility. If it suggests, however, that no impairment of visibility in such areas can be considered "significant" under the statute, the Report seems quite misguided.

In some of these respects Congress might reasonably have gone further. In general, however, whether the visibility provisions will have their intended effect will mevitably depend upon how costs and benefits are compared.

The statute unfortunately appears to leave the comparison largely to the states, whose failure to protect the parks in the first place gave rise to the federal provisions. "Best available retroflt technology" is to be "determined by the State" if a state plan has been approved, except that in the case of power plants of over 750-megawatt capacity the determination must be made "pursuant to guidehines" promulgated by the EPA. ${ }^{209}$ The plan is to contam "emission limits"210 reflecting that

204. Id. \& 7491(g)(2).

205. Major sources are defined somewhat differently than for PSD purposes.

206. H.R. ReP. No. 294, 95th Cong., 1st Sess. 206, reprinted in [1977] U.S. Code CoNa. \& AD. NEwS 1077, 1285.

207. 42 U.S.C. $§ 7491$ (c) (Supp. I 1979).

208. H.R. Rep. No. 294, 95th Cong., Ist Sess. 207, reprinted in [1977] U.S. Code Cona. \& AD. NEWS 1077, 1286.

209. 42 U.S.C. \& 7491(b)(2) (Supp. I 1979).

210. Id. 
determination, ${ }^{211}$ and the plan is subject to EPA scrutiny for conformity to the statute. The specific clause "as determined by the State," however, may unfortunately immunize the definition of best retrofit from that review. Similarly, it is the state that is to determine, apparently without federal review, whether a source has the effect on visibility requisite to trigger the retrofit requirement. If a state is too lax im either respect, the Administrator may apparently compensate by alternative provisions in the regulations "to assure . . . reasonable progress toward meetimg the national goal."

Although section 169A(a)(1) declared it part of the national goal to prevent future impairment of visibility, the Conference Report, stressing that "a major concern" in its adoption was existimg impairment, declared that "issues with respect to visibility as an air quality value $\mathrm{m}$ application to new sources are to be resolved within the procedures for prevention of significant deterioration."212 The suggestion that the visibility provisions impose no additional requirements for new sources seems incompatible with the statute, which requires "reasonable progress" toward the national goal. The nondegradation provisions seem madequate to fill the gap. Section 165(d)(2)(C)(ii) does allow consideration of visibility impairment resulting from new sources of pollutants although no relevant increments are offended, ${ }^{213}$ but only when major sources are to be constructed. The requirement of "reasonable progress" respecting visibility is not so limited.

It seems a pity that no similar provisions are made for other nuisances affectimg mandatory class $I$ areas. The stench of a single pulp mill, for example, can spoil the enjoyinent of many square miles of an otherwise idyllic area. The statute should protect class I areas from offensive odors as well. ${ }^{214}$

211. See H.R. REP. No. 564, 95th Cong., 1st Sess. 155, reprinted in [1977] U.S. CoDE CONG. \& AD. News 1502, 1536, stating also that the determination is to be made "on a source-by-source basis to be included in the State implementation plan."

212. Id. Senator Muskie also denied the visibility provisions would apply to new sources with PSD permits. 123 CoNG. REC. S13709 (daily ed. 1977). See Tundermann, supra note 181, concludimg on the basis of Muskie's statentent and a contrary indication froin Rep. Rogers that the applicability of the visibility sections to new sources was questionable.

213. See text accompanymg notes 181-82 supra.

214. Guidelines for standards limiting emissions of foul-snelling sulfur compounds from existing kraft pulp mills have recently been adopted under $\$ 111$ (d). See 43 Fed. Reg. 7597 (1978). However, while the new-source standards for pulp mills are said to be stringent enought to "prevent odor problems . . . at most new kraft pulp mills," 43 Fed. Reg. 7568, 7569 (1978), the existing-source standards are significantly less stringent in some respects (20 ppm from lime kilns and recovery furnaces as conipared with 8 and 5 for new plants), and the EPA does not say that they will eliminate odor problems. Moreover, additional types of plants causing significant odor problems may not be covered by $\$ 11 \mathrm{I}(\mathrm{d})$ standards. 


\section{CONCLUSION}

Ambient standards are useful elements of a pollution control program, but there is much to be said for Congress' conclusion that additional measures should be taken to prevent immediate degradation of the entire country to levels set by ambient standards. A best-technology requirement for new sources, dictated both by section 111 and by the deterioration provisions, helps to preserve the opportunity for contimued industrial expansion. Tight absolute limits on degradation and special visibility provisions provide needed protection for scemic areas without requiring the setting of special ambient standards. Increment ceilings for other areas, if not set so strictly as to imterfere seriously with development, furnish a justifiable hedge agamst the danger that harmful effects may occur at levels previously believed safe. The permit requirement makes it possible to prevent violations from happening, which is always better than curing them after they occur.

The basic principles of the PSD provisions, therefore, seem sound if they can be achieved at acceptable cost. As mdicated throughout this Article, lowever, the complex implementing provisions present both serious difficulties of interpretation and questionable policy choices. For example, Congress should clearly provide: (a) that permits are required for major new sources anywhere that will affect attainment areas; (b) that im determining whether a source needs to apply for a permit it slrould not be assumed that control equipment will operate as the owner hopes it will; and (c) that no permit should be required for a source emitting only unregulated pollutants, or for a modification that is not "major." Congress should uncouple the various issues now dependent upon the definition of "source" so that all may be resolved according to statutory policy. It should protect agamst state imdifference by allowing both federal veto of state-issued perinits that offend the PSD requirements and federal classification of federally owned lands. Congress should further define technology requirements in consistent terins under sections 111,165 , and 173 , clarifying whether differences reflect actual policy. It should also make certain that the visibility protections affect new as well as existing sources, and should extend the principle of those provisions to other environinental nuisances. Thus, while PSD is an important attractive concept, the difficult problems of its implementation require contimued scrutiny to assure that Congress and the EPA strike an acceptable balance in the perennial tension between conservation and development. 